\title{
An integrated entrepreneurial performance model focusing on the importance and proficiency of competencies for start-up and established SMEs
}

\author{
M Botha*, J.J. van Vuuren and T. Kunene \\ University of Pretoria, Department of Business Management, Economic and Management Sciences \\ Building, Room 3-53, Lynnwood Road, Pretoria, 0002 \\ *To whom all correspondence should be addressed \\ melodi.botha@up.ac.za
}

\begin{abstract}
Functional and enterprising competencies were identified in the integrated entrepreneurial performance model and the paper highlights which key skills and which supportive skills should be included in entrepreneurial training models and programmes. Functional competencies depend on business management/general business and technical skills. Enterprising competencies depend on entrepreneurial and personal skills. A clear distinction is made between general management and entrepreneurial skills. A multi-sample of 570 start-up and established small and medium enterprises (SMEs) was used to determine whether there are statistically significant differences between the groups in terms of the importance and proficiency in these competencies. Exploratory factor analysis was conducted to confirm the validity and reliability of the measuring instrument and several statistical tests, including t-tests and ANOVAs, were performed to test the hypotheses. Established SMEs considered functional competencies as being much more important than start-ups. This finding implies that start-up SMEs need to focus on the importance of functional competencies if they want to increase their chances of becoming established businesses. It was found that start-up, as well as established SMEs, consider enterprising competencies as important. The established group considered themselves very proficient in both the functional and enterprising competencies while the divergent was true for the start-up group.
\end{abstract}

\section{Introduction}

The importance and contribution of dynamic small businesses and entrepreneurship to economic growth has been widely acknowledged (Eggers, Kraus, Hughes, Laraway \& Snycerski, 2013; Filser \& Eggers, 2014; Henderson \& Weiler, 2010). Critical to aiding small business growth is the understanding of various internal and external factors which determine entrepreneurial performance (Bolton \& Lane, 2012; Van Wyk \& Adonisi, 2012). This study identifies important competencies in an integrated entrepreneurial performance model and investigates how proficient SMEs are in these competencies. The researchers argue that the survival and growth of SMEs will be attributable to having the right competencies and being proficient in those competencies. Many studies emphasise that entrepreneurs must have the right set of skills, however, the problem is that most of the entrepreneurial training programmes and models continue to emphasize general management competencies rather than specific entrepreneurial competencies (Hills, 1988; Jusoh, Ziyae, Asimiran \& Kadir, 2011; Morris, Webb, Fu \& Singhal, 2013; Rasmussen, Mosey \& Wright, 2011; Solomon, Duffy \& Tarabishy, 2002). In this paper the importance of both general management and entrepreneurial competencies are emphasised and a clear distinction is made between these competencies.

A great deal of research has focused on prescribing the skills, competencies and training that entrepreneurs should have (Man, Lau, \& Chan, 2002; Middleton \& Donnellon, 2014;
Morris et al., 2013) and various training models include a range of them. At the same time, some researchers have further empirically tested the skills and how competent entrepreneurs are in them (Morris et al., 2013; Sánchez, 2013; Stuetzer, Obschonka \& Schmitt-Rodermund, 2013; Van Vuuren \& Botha, 2010), although the tendency was to focus on potential (nascent), start-up or student entrepreneurs as their sample (Morris et al., 2013; Sánchez, 2013; Steutzer et al., 2013). The problem with using only start-up entrepreneurs as a sample is that they are newcomers to business and might not have had sufficient experience to acquire the skills needed to operate a business successfully (Morris et al., 2013; Sarasvathy, Menon \& Kuechle, 2013). This is evidenced by the alarmingly high rate of small business closure, implying that SMEs are limited in their ability to create long-term sustainable employment (Cornwall \& Naughton, 2003). The problem with using students as a sample is that they have not started businesses and are mostly exposed to theoretical foundations regarding which skills are needed and might not have sufficient practical experience in starting and running a business (Sarasvathy et al., 2013; Unger, Rauch, Frese \& Rosenbusch, 2011). Sample choices in such studies impede on a good understanding of the skills and competencies SMEs require to ensure entrepreneurial performance in their businesses.

This paper develops an integrated entrepreneurial performance model, by investigating the self-estimated key skills and competencies identified in eight existing entrepreneurial performance models by Darroch and Clover 
(2005), Erikson (2002), Glancey (1998), Man, Lau, and Chan (2002), Perks and Struwig (2005), Ucbasaran, Westhead and Wright (2002), Van Vuuren and Nieman (1999), and Wickham (2001). Van Vuuren and Botha (2010) define an entrepreneurial performance model as a framework of constructs that should be included in an entrepreneurship training intervention to increase business performance. Key competencies are represented by the multiplicative function, signifying that the absence of any one of the elements will lead to zero performance, while weakness in a particular element will decrease the effectiveness in overall performance of the venture. Furthermore, increasing the capacity of any of these competencies can lead to an increase in the entrepreneurial performance.

On the basis of the above discussion and the literature review that follows, the study sought to answer the following research questions: What set of competencies are associated with established entrepreneurs? How important are these competencies as perceived by owners of start-up as well as established SMEs? How proficient do these start-up and established SMEs view themselves and their teams in these competencies? Can the competencies included in the integrated entrepreneurial performance model be applied to both start-up and established SMEs and what are the differences and similarities? The contribution of this study could be that the key skills and supportive skills that should be included in entrepreneurial training programmes and models are identified in the integrated entrepreneurial performance model.

\section{Literature review and hypotheses development}

'Although researchers have devoted considerable effort to identifying characteristics, traits, values, affective states, and cognitive styles that are associated with entrepreneurial success (Baron, 2008; Gartner, 1989), the particular competencies that support venture creation remain elusive. Determining such competencies is further complicated by a failure among scholars to distinguish business skills from entrepreneurial skills' (Morris et al., 2013: 352).

Many studies show that there is a positive relationship between human capital and entrepreneurial performance, which makes owners more efficient in how they run their enterprises and perform complex tasks (Lussier \& Pfeifer, 2001; Marimuthu, Arokiasamy \& Ismail, 2009; Morrison, Breen \& Ali, 2003; Unger et al., 2011). Human capital can be defined as the attitudes, commitment, values, knowledge, experience, education, capability, skills and abilities that help the entrepreneur and his team in the tasks of starting, running and growing the business (Marimuthu et al., 2009; Markman \& Baron, 2003; Unger et al., 2011). The essential competencies and skills include all existing and acquired knowledge that lead to certain behaviour and actions of entrepreneurs. These skills enable owners to identify and evaluate market opportunities; to set up realistic and measurable goals; to secure resources required and set up new ventures; to produce and service the market; to manage conflict effectively and to achieve overall industrial efficiency, as well as effectiveness that leads to the growing of the business. Morris et al., (2013) explain that competency refers to the knowledge, skills, attitudes, values and behaviours that people need to perform a particular activity or task successfully. An emphasis on competencies as a means of capturing key aspects of the entrepreneur that impact venture performance is a relatively new development (Brinckmann, 2007; Morris et al., 2013). This paper aims to make a valuable contribution to prescribing the competencies needed in this new development.

\section{Entrepreneurial performance models}

In entrepreneurship and small business research, a business's performance is often considered the ultimate criterion of success or failure in both empirical studies and theoretical models (Man et al., 2002; Su Xie \& Li, 2011). Therefore the normative theory underlying this research is based on eight models that link entrepreneurship performance with skills and competencies. These eight models were selected for the investigation as they all met the following requirements:

- They were frequently cited by other researchers in highlevel entrepreneurship journals;

- They were empirically tested and evaluated;

- They were all entrepreneurial performance models focused on increasing performance by improving certain skills and competencies.

All these models attempt to specify the predictors of entrepreneurial performance and propose equations of key skills and competencies. Table 1 provides a summary of the equations of these models and which skills and competencies are needed to increase entrepreneurial performance. 
Table 1: Equations of the entrepreneurial performance models

\begin{tabular}{|c|c|c|}
\hline Authors & Equations & Skills and competencies \\
\hline Glancey (1998) & $\begin{array}{l}\text { Increase in performance }=\mathrm{G} \text { (traits, motivation, } \\
\text { management }) \mathrm{xh} \text { (market) }\end{array}$ & $\begin{array}{l}\text { Entrepreneurial characteristics } \\
\text { Managerial practices } \\
\text { Entrepreneur's motivations } \\
\text { Markets in which the business operates }\end{array}$ \\
\hline $\begin{array}{l}\text { Van Vuuren and Nieman } \\
\text { (1999) }\end{array}$ & $\uparrow \mathrm{E} / \mathrm{P}=\mathrm{aM} \times \mathrm{b} \mathrm{E} / \mathrm{S} \times \mathrm{c} \mathrm{B} / \mathrm{S}$ & $\begin{array}{l}\text { Motivation } \\
\text { Entrepreneurial skills } \\
\text { Business skills }\end{array}$ \\
\hline Wickham (2001) & $\begin{array}{l}\uparrow \text { Performance }=\mathrm{W} \text { (industry, management, } \\
\quad \text { interpersonal, motivation) }\end{array}$ & $\begin{array}{l}\text { General management skills } \\
\text { Industry knowledge } \\
\text { Personal motivation } \\
\text { Interpersonal skills }\end{array}$ \\
\hline Erikson (2002) & $\begin{array}{l}\uparrow \text { Performance }=\mathrm{E} \text { (competence and commitment) } \mathrm{x} M \\
\mathrm{x}(\mathrm{B} / \mathrm{S}+\text { opportunity } \mathrm{x} \text { resources })\end{array}$ & $\begin{array}{l}\text { Entrepreneurial competence } \\
\text { Entrepreneurial commitment } \\
\text { Motivation } \\
\text { Opportunity } \\
\text { Resources }\end{array}$ \\
\hline Man et al. (2002) & $\uparrow$ Performance = M (competitive scope, B/S, E/S) & $\begin{array}{l}\text { Competitive scope } \\
\text { Organisational competencies (business skills) } \\
\text { Entrepreneurial competencies (entrepreneurial } \\
\text { skills) }\end{array}$ \\
\hline Ucbasaran et al. (2002) & Success $=\mathrm{U}(\mathrm{E} / \mathrm{S}, \mathrm{B} / \mathrm{S}$, Technical $)$ & $\begin{array}{l}\text { Entrepreneurial role } \\
\text { Managerial role } \\
\text { Technical role }\end{array}$ \\
\hline Darroch and Clover (2005) & Success $=\mathrm{D}($ motivation, E/S, B/S $)$ & $\begin{array}{l}\text { Motivation } \\
\text { Entrepreneurial skills } \\
\text { Business skills }\end{array}$ \\
\hline Perks and Struwig (2005) & Success $=\mathrm{P}($ personal, opportunity, $\mathrm{B} / \mathrm{S}$, technical) & $\begin{array}{l}\text { Personal skills } \\
\text { Technical skills } \\
\text { Business opportunity } \\
\text { Management skills }\end{array}$ \\
\hline
\end{tabular}

From Table 1 it is evident that most of the models include motivation, entrepreneurial skills and business skills as important elements to enhance entrepreneurial performance. These skills are further examined in Table 2, which provides an analysis of the skills constructs identified in the eight different models. From this table it is evident which skills were included in which models and which models did not include certain skills. (Shaded cells indicate skills that were not in some models). 
Table 2: An analysis of the skills constructs as per the eight models reviewed

\begin{tabular}{|c|c|c|c|c|c|c|c|c|}
\hline Skills & $\begin{array}{l}\text { Glancey } \\
1998\end{array}$ & $\begin{array}{l}\text { Van } \\
\text { Vuuren } \\
\text { and } \\
\text { Nieman } \\
1999\end{array}$ & $\begin{array}{l}\text { Wickham } \\
2001\end{array}$ & $\begin{array}{l}\text { Erikson } \\
2002\end{array}$ & $\begin{array}{l}\text { Man et } \\
\text { al. } 2002\end{array}$ & $\begin{array}{l}\text { Ucbasaran } \\
\text { et al. } 2002\end{array}$ & $\begin{array}{l}\text { Darroch } \\
\text { and Clover } \\
2005\end{array}$ & $\begin{array}{l}\text { Perks } \\
\text { and } \\
\text { Struwig } \\
2005\end{array}$ \\
\hline Business skills & $\mathrm{x}$ & $\mathrm{x}$ & $\mathrm{x}$ & $\mathrm{x}$ & & & $\mathrm{x}$ & $\mathrm{x}$ \\
\hline Strategy and business plans & & $\mathrm{x}$ & & & $\mathrm{x}$ & $\mathrm{x}$ & & \\
\hline Operations & & $\mathrm{x}$ & & & & $\mathrm{x}$ & & \\
\hline Financial & & $\mathrm{x}$ & & & $\mathrm{x}$ & $\mathrm{x}$ & & \\
\hline Marketing & & $\mathrm{x}$ & & & $\mathrm{x}$ & $\mathrm{x}$ & & \\
\hline Human resources & & $\mathrm{x}$ & & & $\mathrm{x}$ & $\mathrm{x}$ & & \\
\hline Legal skills & & $\mathrm{x}$ & & & & & & \\
\hline Communication & & $\mathrm{x}$ & & & $\mathrm{x}$ & & & $\mathrm{x}$ \\
\hline Entrepreneurial skills & & $\mathrm{x}$ & & $\mathrm{x}$ & & $\mathrm{x}$ & $\mathrm{x}$ & \\
\hline Industry / market opportunity & $\mathrm{x}$ & $\mathrm{x}$ & $\mathrm{x}$ & $\mathrm{x}$ & $\mathrm{x}$ & $\mathrm{x}$ & & $\mathrm{X}$ \\
\hline Risk & & $\mathrm{x}$ & & & $\mathrm{x}$ & $\mathrm{x}$ & & \\
\hline Creativity & & $\mathrm{x}$ & & & & & & \\
\hline Innovation & & $\mathrm{x}$ & & & $\mathrm{x}$ & & & \\
\hline Role models & & $\mathrm{x}$ & & & & & & \\
\hline Gathering of resources & & & & $\mathrm{x}$ & & & & \\
\hline Personal skills & & & $\mathrm{x}$ & & $\mathrm{x}$ & & & $\mathrm{x}$ \\
\hline Decision-making & & $\mathrm{x}$ & & & $\mathrm{x}$ & & & \\
\hline $\begin{array}{l}\text { Achievement motivation \& } \\
\text { commitment }\end{array}$ & $\mathrm{x}$ & $\mathrm{x}$ & $\mathrm{x}$ & $\mathrm{x}$ & $\mathrm{x}$ & & $\mathrm{x}$ & $\mathrm{x}$ \\
\hline Inner control & & $\mathrm{x}$ & & & & & & \\
\hline Persistence & & $\mathrm{x}$ & & & & & & \\
\hline Leadership & & $\mathrm{x}$ & & & $\mathrm{x}$ & & & \\
\hline Problem solving & & $\mathrm{x}$ & & & & & & $\mathrm{x}$ \\
\hline Ability to learn & & $\mathrm{x}$ & & & & $\mathrm{x}$ & & \\
\hline Networking & & & & & $\mathrm{x}$ & & & \\
\hline Literacy and numeracy & & & & & & & & $\mathrm{x}$ \\
\hline Technical skills & & & & & $\mathrm{x}$ & $\mathrm{x}$ & & $\mathrm{x}$ \\
\hline Product/ service development & & & & & & $\mathrm{x}$ & & \\
\hline Product / service production & & & & & & $\mathrm{x}$ & & \\
\hline
\end{tabular}

\section{Integrated entrepreneurial performance model}

Based on Tables 1 and 2, an integrated model was developed. This was done by including all of the constructs that were identified by reviewing the existing models. However, the following variations were incorporated:

- Following Erikson's (2002) model, the ability to gather resources is included as one of the skills within the entrepreneurial skills construct.

- The integrated model broadens the motivation skills to include all personal skills identified by Man et al., (2002), Perks and Struwig (2005) and Wickham (2001). Therefore the new construct, called 'Personal skills $(\mathrm{P} / \mathrm{S})$ ), is defined as including motivation (need for achievement), problem solving, numeracy and literacy, and communication skills. This integrated model acknowledges that motivation is the dominating factor in the personal skills construct.

- Another category, "Technical skills (T/S)", is identified separately from the business skills following the models of Man et al., (2002) and Ucbasaran et al., (2002). It is clear that an entrepreneur needs certain technical skills (Cornwal \& Naughton, 2003). Perks and Struwig (2005) point out that technical skills should be a precondition for starting any business (because the entrepreneur must create things well). In an entrepreneurial team, one person might possess technical skills and the other business skills; one person seldom has all the skills required. Therefore the technical skills can be considered a multiplicative construct, instead of an additive construct, as part of the portfolio in business skills.

On the basis of the above, this research posits in Figure 1 that the integrated entrepreneurial performance model can be divided into two sets of competencies, namely enterprising and functional competencies. Enterprising competencies are abilities responsible for the booster/energizer/enterprising functions which assist with business development and motivation. These depend on entrepreneurial and personal skills. Functional competencies assist the entrepreneur to function in the business and find the balance between opportunity, resources and the entrepreneurial team. These depend on business management/general business and technical skills. These two competencies are supported by the literature as interdependent and complementary categories required by entrepreneurs in order to succeed (Kodithuwakhu \& Rosa 2002; Mitchelmore \& Rowley 2010; Rwigema \& Karungu 1999; Schamp \& Deschoolmeester 1998). Therefore the integrated model posits that the increase in 
entrepreneurial performance is dependent on the availability of enterprising and functional competencies.

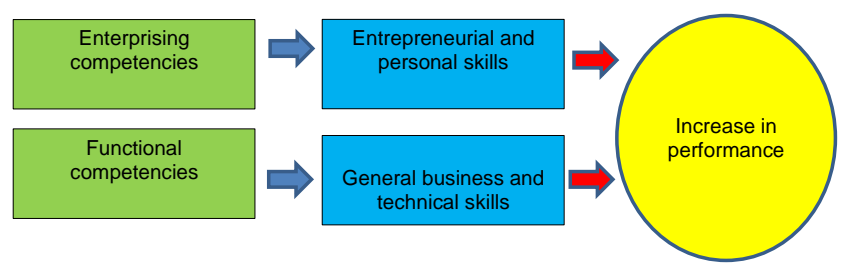

Figure 1: The link between competencies and skills

The integrated model for increasing entrepreneurial performance is best represented by the equation below:

$\uparrow \mathrm{E} / \mathrm{P}=(\mathrm{a} . \mathrm{P} / \mathrm{S} \times \mathrm{b} . \mathrm{E} / \mathrm{S}) \times(\mathrm{c} . \mathrm{B} / \mathrm{S} \times \mathrm{d} . \mathrm{T} / \mathrm{S})$

where:

- $\quad \uparrow E / P$ is defined as Entrepreneurial Performance, which is based on starting a business, utilizing an opportunity and growing the business idea.

- $\mathrm{P} / \mathrm{S}$ is Personal skills, which include the following: problem solving, numeracy and literacy, motivation (need for achievement), and communication.

- $\quad \mathrm{E} / \mathrm{S}$ is Entrepreneurial skills, which cover the ability to turn business ideas into feasible business opportunities, to start and to grow a business enterprise. Entrepreneurial skills include creativity, innovation, opportunity recognition, role model interpretation, ability to gather and control resources and calculated risk taking.

- $\mathrm{B} / \mathrm{S}$ is Business skills, which cover all the conventional management areas in a business. B/S includes financial, business systems management, general management, human resources, ICT skills, legal skills, marketing, networking, operational, planning, research and development, and supplier management skills.

- $\mathrm{T} / \mathrm{S}$ is Technical skills, including vocational and specialised expertise that enables the business to develop and produce the products and services at an acceptable quality.

- $\quad \mathrm{a}, \mathrm{b}, \mathrm{c}$ and $\mathrm{d}$ are constant coefficients.

This integrated model, as described by the equation, forms the normative theory for the empirical section of the paper. Supportive skills are represented by additive functions, signifying that the absence of any of these skills will reduce performance yet not completely destroy the business. This also means that increasing the capacity of any of these skills enhances performance. They are mentioned in Table 3, where the statistical tests presented later in the paper revealed which functional and enterprising competencies were viewed as being more important than other competencies. The competencies that were viewed as being very important to established SMEs were included as Key skills and the competencies that were viewed as not being very important were included as Supportive skills. The importance of the competencies was tested and compared between the start-up and established SMEs in Hypotheses 1 and 2.

Hypothesis 1: Owners of the established SMEs consider functional competencies to be more important than the owners of the start-up SMEs.

Hypothesis 2: Owners of the established SMEs consider enterprising competencies to be more important than the owners of the start-up SMEs.

Table 3: List of functional and enterprising competencies required by SMEs

\begin{tabular}{l|l}
\hline \multicolumn{2}{c}{ FUNCTIONAL COMPETENCIES } \\
\hline Identification in model & Key skills \\
\hline BM & Marketing management \\
\hline BF & Financial management \\
\hline BO & Operational \\
\hline BL & Legal skills \\
\hline Identification in model & Supportive skills \\
\hline BG & General management \\
\hline BI & ICT skills \\
\hline BH & Human resources management \\
\hline BN & Networking \\
\hline BP & Planning \\
\hline BR & Research and development \\
\hline BS & Business Systems management \\
\hline BV & Value chain management \\
\hline T/S & Technical Skills \\
\hline PN & Numeracy and literacy \\
\hline PC & Communication \\
\hline ENTERPRISING COMPETENCIES \\
\hline Identification in model & Key skills \\
\hline EG & Ability to Gather \& control resources \\
\hline PM & Motivation (need for achievement) \\
\hline Identification in model & Supportive skills \\
\hline EC & Creativity \\
\hline EI & Innovation \\
\hline EM & Role Model interpretation \\
\hline EO & Opportunity recognition \\
\hline ER & Calculated Risk taking \\
\hline PLS Persontife skills &
\end{tabular}

PLS - Personal life skills including adaptability to change, decision-making, negotiating skill learning abilities, problem solving, time management skills

Founded on the simplified integrated model above, the study posits that performance of SMEs will be attributable to entrepreneurs having all the key and supportive skills as identified in Table 3. This study was theoretically based on the following integrated entrepreneurial performance model that is derived from the eight models investigated:

"Training for $\uparrow \mathrm{E} / \mathrm{P}=$ training in key skills $\mathrm{x}[1+$ training in supporting skills]".

Key skills $=[$ a.PM $x$ q.EG $x(s . B F \times$ t.BM $x$ y.BL $x$ $\alpha . \mathrm{BO})]$

Supportive skills $=[(1+$ e.PLS + j.PN+ f.PC $) \times(m . E O+$ n.EC + o.EI $)) \times(1+$ p.EM $) \times$ r. $(1 /(1-E R) \times((1+\mathrm{v} \cdot B S=$ 

w.BG $+x \cdot B I+z \cdot B N+u \cdot B H+\beta \cdot B P+\square \cdot B R+\square \cdot B V) x$
d.T/S $]$

It is necessary to determine not only how important these competencies are to the start-up and established SMEs but also how proficient they are in these competencies. This will indicate whether the two groups have the requisite skills identified in each of the competencies identified in the integrated model. The proficiency of the competencies are tested and compared between the two groups in Hypotheses 3 and 4.

Hypothesis 3: Owners of the established SMEs are more proficient in functional competencies than the owners of the start-up SMEs.

Hypothesis 4: Owners of the established SMEs are more proficient in enterprising competencies than the owners of the start-up SMEs.

\section{Methodology}

A cross-sectional, ex post facto, quantitative study of 570 SMEs (197 established and 373 start-up businesses) was used to investigate the research questions. A structured questionnaire (survey) was used as the instrument to collect data. The final competency categories chosen were a combination of skills identified in the literature review. In the survey, the skills were combined into categories as follows:

- The study combines the following skills under the heading "self-motivation": perseverance with patience, determination, persistence, resilience, dedication, selfconfidence, confidence building, self-esteem, selfefficacy commitment, positive attitude, aptitude to learn and a realistic approach.

- The study combines problem solving, time management, decision-making, ability to handle stress, ability to handle change, learning ability and negotiating into a category called "life skills".

- Business linkages, industrial clustering and networking are combined into one category.

- Identification of market opportunities, innovation and creativity were grouped in the "opportunity alertness" category.

- The "planning" category includes general management, strategy development, planning, business plan development, organizational control, organizing, strategic awareness and orientation, basic business skills and project management.

- Competition analysis was included in the "marketing" category.

This resulted in the list of skill categories that is presented in Table 3. A three-point Likert scale was used for categorizing levels of the small business awareness regarding the importance and proficiency of the competencies.

To confirm the validity and reliability of the measuring instrument, exploratory factor analysis (EFA) was carried out. In this study, factor analysis was applied to two sets of variables, the first set measures the importance of the skills and competencies, while the second set measures the proficiency of the SMEs in these skills and competencies. Figure 2 was used to explain the first and second sets, in order to give a clearer picture of how factor analysis was conducted.

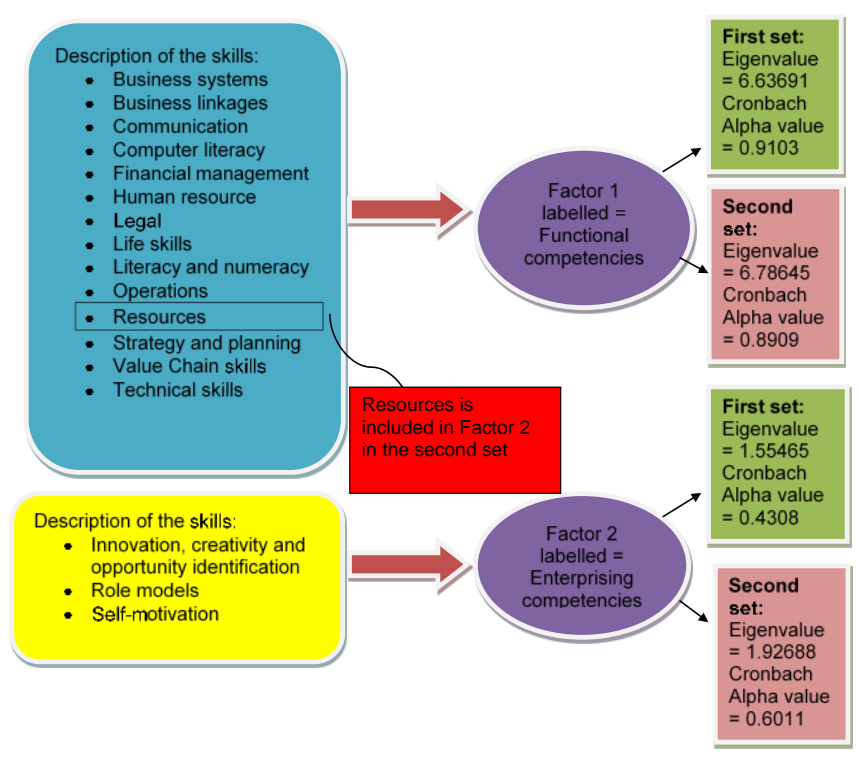

Figure 2: Observed factors as produced from EFA

For the first set of variables testing the importance of the skills and competencies, the 17 items, posed on a three-point Likert scale, delivered an excellent Cronbach Alpha result. A value of 0.8854 was obtained for all the variables used. The Cronbach Alpha for factor 1 was acceptable at 0.9103, which indicated that the instrument actually measured the concepts aimed to be measured and signified internal consistency. The Cronbach Alpha for factor 2 was not acceptable as it was very low at 0.4308 . Low Cronbach alphas indicate low validity and reliability of the factor. Normally, such a factor would be excluded in a research study. However, it was decided to include the second factor and accept the low Cronbach alpha because the second factor items were similar to the enterprising competencies category that was identified in the literature review. The low value of 0.4308 may be due to the small number of variables (Kim \& Mueller, 1988). Factor 2 has only three variables as opposed to 14 variables in factor 1. Categorising innovation, opportunity identification and creativity into one skill category instead of three may also have played a role.

For the second set of variables, testing the proficiency of the SMEs in the skills and competencies, the 17 items, posed on a three-point Likert scale, an excellent Cronbach Alpha result. A value of 0.8881 was obtained for all the variables used. The Cronbach Alpha results for factors 1 and 2 were acceptable at 0.8909 and 0.6011 , respectively. It is interesting to note that the ability to gather and control resources is seen as a functional competency when examining the factor analysis of the importance question. However, in the proficiency question, the same skill (ability to gather resources) came out as an enterprising competency. 
Sampling design

Targeted respondents included small business owners, owner-managers and start-up (emergent) entrepreneurs. The target respondents had to meet these criteria:

- They operate in the geographic proximity of Gauteng province, South Africa.

To secure the sample, a list of SMEs in South Africa was compiled from various sources and SME agencies, including: business projects trained by the Department of Labour (DOL) in all its Skills Development Programmes; lists of projects and SMEs registered at the Premier's Office in Gauteng; SME and project list with the City of Johannesburg Municipal Departments engaged in development projects; National SME statistics from the South African Revenue Services (SARS); and SME and project lists with the Department of Trade and Industry (DTI) and its registrar of companies.

- They are actively running the business.

- Age, size and number of employees were used as performance indicators to determine which respondents fell into the start-up and which in the established groups.

The final sample was composed of 570 SMEs. Of the targeted sample of 700 SMEs of 350 per sub-sample, 600 were collected and acceptable yielding an $85 \%$ response rate. Two purposive samples were derived from the division of the responses elicited, based on the following criteria: 197 SMEs had more than 5 employees, earned more than R150 000 and were in existence as businesses for more than three years. 373 SMEs were considered as start-up SMEs as they had fewer than 5 employees or an annual turnover of less than R150 000 or had been in business for less than three years. Thirty questionnaires were excluded as they had too many missing or incorrect entries.

\section{Findings}

Both the established and the start-up samples had similar demographic and business biographical characteristics which allowed the samples to be compared. The t-tests were executed on the established and start-up groups by comparing whether there were statistically significant differences between the mean scores of the variables categorised in the two factors, namely functional and enterprising competencies (refer to Table 4). Each skill within the functional and enterprising competencies was also tested individually and the discussion thereof is presented later in the paper. The Levene $\mathrm{F}$ test for equal variance indicated the validity of performing a t-test.

Table 4: Independent t-test - on importance of functional and enterprising competencies

\begin{tabular}{l|c|c|c|c|c}
\hline \multirow{2}{*}{ Importance - Factor } & \multicolumn{2}{|c|}{ Mean } & \multicolumn{2}{c|}{ Std Deviation } & \multirow{2}{*}{ P value } \\
\cline { 2 - 5 } & Established & Start-up & Established & Start-up & $<0.0001^{* *}$ \\
\hline Functional competencies & 3.4013 & 2.9970 & 0.3240 & 0.6603 & 0.2213 \\
\hline $\begin{array}{l}\text { Enterprising } \\
\text { competencies }\end{array}$ & 3.2673 & 3.2028 & 0.3922 & & \\
$\begin{array}{l}\text { *Significant at } \mathrm{p}=0.05 \text { level } \\
\text { SS }\end{array}$ & & & & & \\
\hline
\end{tabular}

** Significant at $\mathrm{p}=0.05$ level

There were statistically significant differences $(\mathrm{p}=<0.0001$ which is < 0.01) between the established group and the startup group with regard to the importance of functional competencies. On average, the established group tend to perceive functional competencies as more important than the start-up group. There was no statistically significant difference ( $p=0.2213$ ) between the two groups with regard to the importance of enterprising competencies. Both groups tend to consider enterprising competencies to be important for business performance. This makes sense as both groups feel that entrepreneurial skills, which are included in enterprising competencies, are important when starting and managing an own business.

Table 5 highlights ANOVA outputs and the significance of source tested for factor 1 (functional competencies) and factor 2 (enterprising competencies), comparing the established and start-up SMEs in terms of their views of the importance of the competencies in the two factors.

Table 5: ANOVA of the difference between the SMEs concerning importance

\begin{tabular}{l|c|c|c|c|c|c}
\hline \multirow{2}{*}{ Factor } & \multicolumn{2}{|c|}{ Mean } & \multicolumn{2}{c|}{ Coeff Var } & \multicolumn{2}{c}{ R square } \\
\cline { 2 - 7 } & $\begin{array}{c}\text { Established } \\
\text { group }\end{array}$ & $\begin{array}{c}\text { Start-up } \\
\text { group }\end{array}$ & $\begin{array}{c}\text { Established } \\
\text { group }\end{array}$ & $\begin{array}{c}\text { Start-up } \\
\text { group }\end{array}$ & $\begin{array}{c}\text { Established } \\
\text { group }\end{array}$ & Start-up group \\
\hline $\begin{array}{l}\text { Functional } \\
\text { competencies }\end{array}$ & 3.401378 & 2.997128 & 9.290680 & 21.32495 & 0.097172 & 0.090927 \\
\hline $\begin{array}{l}\text { Enterprising } \\
\text { competencies }\end{array}$ & 3.267343 & 3.202860 & 11.46371 & 17.15641 & 0.134277 & 0.071752 \\
\hline
\end{tabular}


The chi-square test for association was performed to indicate the relationship between the start-up and established businesses regarding the importance of individual skills, as included in the integrated entrepreneurial performance model. The chi-square test as well as findings in Figure 3 confirms the findings in the t-test, where the established group of SMEs consider functional competencies to be more important than the start-up group. However, both groups are very close in terms of how they view the importance of the enterprising competency factor. The established group has less variance in terms of their views than the start-up group. Based on the above tests, Hypothesis 1: Owners of the established SMEs consider functional competencies to be more important than the owners of the start-up SMEs, is accepted. Hypothesis 2: Owners of the established SMEs consider enterprising competencies to be more important than the owners of the start-up SMEs, is rejected.
Proficiency: The chi-square test for association was performed to indicate the relationship between the established and the start-up groups concerning their proficiency in certain skills and competencies towards entrepreneurial performance. The results indicate that all the skill variables, except for risk management where $p=0.1807$, were statistically significantly associated with the proficiency level rating at the 0.0001 level of significance. This indicates that the established and start-up groups differ with regard to the proficiency of the skills and competencies. Table 6 highlights the t-test by comparing whether there were statistically significant differences between the mean scores of the variables categorised in the two factors, namely functional and enterprising competencies.

Table 6: Independent t-test - on proficiency of competencies

\begin{tabular}{|c|c|c|c|c|c|}
\hline \multirow{2}{*}{ Competence Factor } & \multicolumn{2}{|c|}{ Mean } & \multicolumn{2}{|c|}{$\begin{array}{l}\text { Std Deviation } \\
\end{array}$} & \multirow{2}{*}{$P$ value } \\
\hline & Established & Start-up & Established & Start-up & \\
\hline Functional competencies & 3.2475 & 2.5243 & 0.3153 & 0.6705 & $<0.0001 * *$ \\
\hline Enterprising competencies & 3.1154 & 2.8185 & 0.4632 & 0.5985 & $<0.0001 * *$ \\
\hline
\end{tabular}

*Significant at $\mathrm{p}=0.05$ level

$* *$ Significant at $\mathrm{p}=0.001$ level

There were statistically significant differences $(\mathrm{p}=<0.0001)$ in the way the established group perceived themselves to be proficient in factor 1 and factor 2 . The established group considered themselves very proficient in both the functional and enterprising competencies, while the owners in the startup group considered themselves not very proficient or just proficient in both competency factors. Interestingly, the established group considered themselves to be more proficient in functional competencies, while the start-up group considered themselves to be more proficient in enterprising competencies. This finding may explain why there was no statistically significant difference between the start-up and the established groups concerning the importance of enterprising competencies.

Table 7 highlights ANOVA outputs and the significance of source tested for factor 1 and factor 2 comparing the established and start-up SMEs in terms of their views of their proficiency in the two factors.

Table 7: ANOVA of the difference between the SMEs on proficiency

\begin{tabular}{l|c|c|c|c|c|c}
\hline \multirow{2}{*}{ Factor } & \multicolumn{2}{|c|}{ Mean } & \multicolumn{2}{c|}{ Coeff Var } & \multicolumn{2}{c}{ R square } \\
\cline { 2 - 6 } & $\begin{array}{c}\text { Established } \\
\text { group }\end{array}$ & $\begin{array}{c}\text { Start-up } \\
\text { group }\end{array}$ & $\begin{array}{c}\text { Established } \\
\text { group }\end{array}$ & $\begin{array}{c}\text { Start-up } \\
\text { group }\end{array}$ & $\begin{array}{c}\text { Established } \\
\text { group }\end{array}$ & Start-up group \\
\hline $\begin{array}{l}\text { Factor 1 functional } \\
\text { competencies }\end{array}$ & 3.248 & 2.254 & 9.355 & 24.038 & 0.119 & 0.205 \\
\hline $\begin{array}{l}\text { Factor 2- enterprising } \\
\text { competencies }\end{array}$ & 3.115 & 2.819 & 13.186 & 19.627 & 0.254 & 0.171 \\
\hline
\end{tabular}

R square cannot exceed 1

Although the ANOVA results show that both groups are close in terms of how they rate their proficiency in the enterprising competencies factor, the established group consider themselves to be more proficient in enterprising competencies than the start-up group. The established group has less variance in terms of how they rated themselves than the start-up group.

The chi-square test revealed that the majority of the established SMEs considered themselves extremely proficient in four skills, namely: financial management, marketing, operations and self-motivation. In terms of importance, four (finance, marketing, self-motivation and securing resources) of the six skills were indicated as key, while in terms of proficiency, three (finance, marketing and self-motivation) of the six proposed key skills were identified. This implies that human resources, opportunity identification and technical skills were not extremely important and so could be said to be important supporting skills. Interestingly, only a few of the established SMEs considered themselves to be extremely proficient in the securing of resources skill category, which was considered by both groups as extremely important. Based on the above tests, Hypothesis 3: Owners of the established SMEs are more proficient in functional competencies than the owners of the start-up SMEs, is accepted. Hypothesis 4: Owners of the 
established SMEs are more proficient in enterprising competencies than the owners of the start-up SMEs, is also accepted.

\section{Discussion of findings}

One of the key findings was that established SMEs viewed functional competencies as being more important compared to start-up SME owners. This corresponds with previous research studies (Morris et al., 2013:365; Sarasvathy et al., 2013: 417-418). There was no difference in their views in respect of enterprising competencies. This might be due to the fact that all entrepreneurs, at various levels of the entrepreneurial process, know that entrepreneurial skills are important in order for the venture to perform successfully (Morris et al., 2013; Sánchez, 2013; Stuetzer et al., 2013; Van Vuuren \& Botha, 2010). It was also noted that the majority of both established and start-up SMEs considered the following skills to be very important: motivation, securing resources, operations, financial management, legal skills and marketing. It is, however, very difficult to find other studies that focus on both established and start-up SMEs simultaneously to enable a comparison of the findings in this paper.

Using Chi-square tests, the results indicated that established SME owners were more likely to perceive themselves as being more proficient than those of start-up businesses. In terms of importance, four (finance, marketing, selfmotivation and securing resources) were indicated as key skills. In terms of proficiency, three skills (finance, marketing and self-motivation) were identified. The implication for theory is that functional and enterprising competencies were identified in the integrated entrepreneurial performance model that should be included in future entrepreneurial performance models and programmes. From this study, six important key skills was identified, namely marketing, finance, operational, legal skills, gather and control of resources and self-motivation, that should be included in entrepreneurial performance models. Furthermore, sixteen additional supporting skills were identified that could be included in entrepreneurial performance models. The implication for practice is that in order for start-up businesses to become established businesses, they should focus more on the importance of functional competencies when starting a business and not only on enterprising competencies. In contrast, many start-up SMEs considered themselves to be just proficient in marketing and operations but not proficient at all in financial and legal skills. Therefore, financial and legal skills should receive more attention when starting a business. Established businesses should focus on the securing resources category, in which they indicated that they were not at all proficient.

\section{Contribution and limitation of the study}

The study incorporated eight models from previous scholars into an integrated and more comprehensive model. This could have significant benefits for entrepreneurship education, entrepreneurial learning, entrepreneurial support, public policy and the practice of entrepreneurship itself. One of the benefits could be that start-up training programmes should include the competencies and skills that established SMEs identified as being important to them. This would increase the chances of start-up SMEs becoming established businesses. The research generated two factors, namely functional and enterprising competencies, which encompassed most of the business skills and entrepreneurship skills constructs of the eight models. This study focused on both entrepreneurial and business skills in the enterprising and functional competencies identified in the integrated entrepreneurial performance model. This makes a contribution to the field of entrepreneurship education as most of the entrepreneurial training programmes and models continue to emphasize general management competencies rather than specific entrepreneurial competencies (Morris et al., 2013; Jusoh et al., 2011; Rasmussen et al., 2011; Solomon et al., 2002; Hills, 1988). The success of SMEs will be attributable to having the right set of competencies as identified in this entrepreneurial performance model and being proficient in those competencies. A further contribution of the study is that a multi-sample, of start-up and established SMEs, was used and compared as opposed to using only a start-up sample. The contribution hereof is that established businesses could indicate which competencies are important to them in their current phase of their businesses and start-up businesses could learn from them.

No study is without its limitations. Based on the stochastic nature of business venturing, there are views that reject the notion that business performance can be equated with entrepreneurial competence. The goal of this study was not prediction but a focus on understanding differences in the perceptions of owners of established SMEs compared to those of start-ups. Hence, there was no attempt to measure business performance but rather to use the longevity of the SMEs as a distinguishing criterion. It must be noted that skills development is only a part of the complex set of variables needed for SMEs to become established businesses. This paper focuses on investigating competencies, as one such variable, as contributing to the process of becoming established businesses. Although self-assessment studies can be considered to be biased, this study still makes a contribution by identifying which skills are seen as being key skills and which are seen as being supportive skills for SMEs starting and managing a venture. In spite of the limitations, the results of this study do shed light on differences in the human capital competency set of owners of established businesses compared to those of start-up businesses.

\section{Recommendations and future research}

Firstly, the study recommends that the training of SMEs should focus on the development of those skills and competencies identified as key to becoming an established business. Based on the model developed, the study recommends that small business skills development and training programmes should apply the model as described by the following equations: 
Training for $\uparrow \mathrm{E} / \mathrm{P}=$ training in key skills $\mathrm{x}[1+$ training in supporting skills].

Key skills $=[$ a.PM $x$ q.EG $x($ s.BF $x$ t.BM $x$ y.BL $x$ $\alpha . \mathrm{BO})]$

Supportive skills $=[(1+$ e.PLS + j.PN+ f.PC $) \times(m . E O+$ n.EC + o.EI $)) \times(1+$ p.EM $) \times$ r. $(1 /(1-E R) \times((1+$ v.BS $=$ $\mathrm{w} \cdot \mathrm{BG}+\mathrm{x} \cdot \mathrm{BI}+\mathrm{z} \cdot \mathrm{BN}+\mathrm{u} \cdot \mathrm{BH}+\beta \cdot \mathrm{BP}+\square \cdot \mathrm{BR}+\square \cdot \mathrm{BV}) \mathrm{x}$ d.T/S]

Secondly, key functional competencies (namely finance, marketing, operations and legal skills) and key enterprising competencies (motivation and the securing/controlling of resources skills) should be integrated into all training programmes of SMEs at all stages of the entrepreneurial process. Thirdly, entrepreneurship education providers (public and private), as well as mentors and consultants who focus on entrepreneurship development should be able to determine the level of proficiency for each trainee in each area, be able to deliver a basic course focusing on transferring the basic comprehension level and be able to provide training in all the key skills competencies. Finally, in future studies, this integrated entrepreneurial performance model could be tested empirically in a longitudinal study to determine if entrepreneurial performance did indeed increase.

\section{References}

Baron, R.A. 2008. 'The role of affect in the entrepreneurial process', Academy of Management Review, 33(2): 328-340.

Bolton, D.L. \& Lane, M.D. 2012. 'Individual entrepreneurial orientation: Development of a measurement instrument', Education and Training, 54(2/3): 1-20.

Brinckmann, J. 2007. 'Competence of top management teams and success of new technology-based businesses'. Germany: Deutscher Universitäts-Verslag.

Cornwall, J.R. \& Naughton, M.J. 2003. 'Who is the good entrepreneur? An exploration within the Catholic social tradition', Journal of Business Ethics, 44(1): 61-75.

Darroch, M.A. \& Clover, T.A. 2005. 'The effects of entrepreneurial quality on the success of small, medium and micro agribusinesses in KwaZulu-Natal, South Africa', Agrekon, 44(3): 321-343.

Eggers, F., Kraus, S., Hughes, M., Laraway, S. \& Snycerski, S. 2013. 'Implications of customer and entrepreneurial orientations for SME growth', Management Decision, 51(3): 524-546.

Erikson, T. 2002. 'Entrepreneurial capital: the emerging venture's most important asset and competitive advantage', Journal of Business Venturing, 17(3): 275-290.

Filser, M. \& Eggers, F. 2014. 'Entrepreneurial orientation and business performance: A comparative study of Austria, Liechtenstein and Switzerland', South African Journal of Business Management, 45(1): 55-65.

Gartner, W.B. 1989. 'Who is an entrepreneur is the wrong question', Entrepreneurship: Theory and Practice, 13(4): 47-68.
Glancey, K. 1998. 'Determinants of growth and profitability in small entrepreneurial businesses', International Journal of Entrepreneurial Behaviour \& Research, 4(1): 18-27.

Hills, G.E. 1988. 'Variations in university entrepreneurship education: an empirical study of an evolving field', Journal of Business Venturing, 3(2): 109-122.

Henderson, J. \& Weiler, S. 2010. 'Entrepreneurs and job growth: Probing the boundaries of time and space', Economic Development Quarterly, 24(1): 23-32.

Jusoh, R., Ziyae, B., Asimiran, S., \& Kadir, S.A. 2011. 'Entrepreneur training needs analysis: Implications on the entrepreneurial skills needed for successful entrepreneurs', International Business \& Economics Research Journal, 10(1): 143-148.

Kim, J.O. \& Mueller, C.W. 1988. Factor analysis: Statistical methods and practical issues. Beverly Hills, CA: Sage

Kodithuwakhu, S.S. \& Rosa, P. 2002. 'The entrepreneurial process and economic success in a constrained environment', Journal of Business Venturing, 17(5): 431-465.

Lussier, R.N. \& Pfeifer, S. 2001. 'A cross-national prediction model for business success', Journal of Small Business Management, 39(3): 228-239.

Man, T.W., Lau, T. \& Chan, K.F. 2002. 'The competitiveness of small and medium enterprises: a conceptualization with focus on entrepreneurial competencies', Journal of Business Venturing, 17(2): 123-142.

Markman, G.D. \& Baron, R.A. 2003. 'Person-entrepreneurship fit: why some people are more successful as entrepreneurs than others', Human Resource Management Review, 13(2): 281-301.

Marimuthu, M., Arokiasamy, L. \& Ismail, M. 2009. 'Human capital development and its impact on business performance: Evidence from developmental economics', The Journal of International Social Research, 2(8): 265-272.

Middleton, K. \& Donnellon, A. 2014. 'Personalizing Entrepreneurial Learning: A Pedagogy for Facilitating the Know Why', Entrepreneurship Research Journal, 4(2): 167-204.

Mitchelmore, S. \& Rowley, J. 2010. 'Entrepreneurial competencies: a literature review and development agenda', International Journal of Entrepreneurial Behaviour and Research, 16(2): 92-111.

Morris, M.H., Webb, J.W., Fu, J. \& Singhal, S. 2013. 'A competency-based perspective on entrepreneurship education: Conceptual and empirical insights', Journal of Small Business Management, 51(3): 352-369.

Morrison, A., Breen, J. \& Ali, S. 2003. 'Small business growth: intention, ability, and opportunity', Journal of Small Business Management, 41(4): 417-425.

Perks, S. \& Struwig, M. 2005. 'Skills necessary to grow micro entrepreneurs into small business entrepreneurs: management', South African Journal of Economic and Management Sciences, 8(2): 171. 
Rasmussen, E., Mosey, S. \& Wright, M. 2011. 'The evolution of entrepreneurial competencies: A longitudinal study of university spin-off venture emergence', Journal of Management Studies, 48(6): 1341-1345.

Rwigema, H. \& Karungu, P. 1999. 'SMME development in Johannesburg's Southern Metropolitan Local Council: an assessment', Development Southern Africa, 16(1): 107-124.

Sánchez, J.C. 2013. 'The Impact of an Entrepreneurship Education Program on Entrepreneurial Competencies and Intention', Journal of Small Business Management, 51(3): 447-465.

Sarasvathy, S.D., Menon, A.R. \& Kuechle, G. 2013. 'Failing businesses and successful entrepreneurs: Serial entrepreneurship as a temporal portfolio', Small Business Economics, 40(2): 417-434.

Schamp, T. \& Deschoolmeester, D. 1998. 'Strategic and operational planning attitudinal changes and the survival and growth of business start-ups revisited: Management training matters', International Journal of Entrepreneurial Behaviour and Research, 4(2): 141-177.

Solomon, G. T., Duffy, S. \& Tarabishy, A. 2002. 'The state of entrepreneurship education in the United States: a nationwide survey and analysis', International Journal of Entrepreneurship Education, 1(1): 65-86.

Stuetzer, M., Obschonka, M. \& Schmitt-Rodermund, E. 2013. 'Balanced skills among nascent entrepreneurs', Small Business Economics, 41(1): 93-114.

Su, Z., Xie, E. \& Li, Y. 2011. 'Entrepreneurial orientation and business performance in new ventures and established businesses', Journal of Small Business Management, 49(4): 558577.

Ucbasaran,D., Westhead, P. \& Wright, M. 2002. 'Human capital based determinants of opportunity identification'. URL: http:// http://fusionmx.babson.edu/entrep/fer/BABSON2003/XVI/XVIP4/XVI-P4.html. Accessed 28 January 2013.

Unger, J. M., Rauch, A., Frese, M. \& Rosenbusch, N. 2011. 'Human capital and entrepreneurial success: A meta-analytical review', Journal of Business Venturing, 26(3): 341-358.

Van Vuuren, J. \& Botha, M. 2010. 'The practical application of an entrepreneurial performance training model in South Africa,, Journal of Small Business and Enterprise Development, 17(4): 607-625.

Van Vuuren, J.J. \& Nieman, G.H. 1999, 'Entrepreneurship education and training: a model for syllabi/curriculum development'. URL: http:// http://scholar.google.co.za/scholar?hl=en\&q=Entrepreneurial+educ ation+and+training $\% 3 \mathrm{~A}+\mathrm{a}+$ model+for+syllabi $\% 2$ Fcurriculum+dev elopment $\% 2 \mathrm{C} \&$ btnG $=\&$ as $\_$sdt $=1 \% 2 \mathrm{C} 5 \&$ as $\_$sdtp $=$. Accessed 12 November 2012.

Van Wyk, R. \& Adonisi, M. 2012. 'Antecedent of corporate entrepreneurship', South African Journal of Business Management', 43(3): 65-78.

Wickham, P. 2001. Strategic entrepreneurship: A decision-making approach to new venture creation and management. Harlow: Pearson. 
